
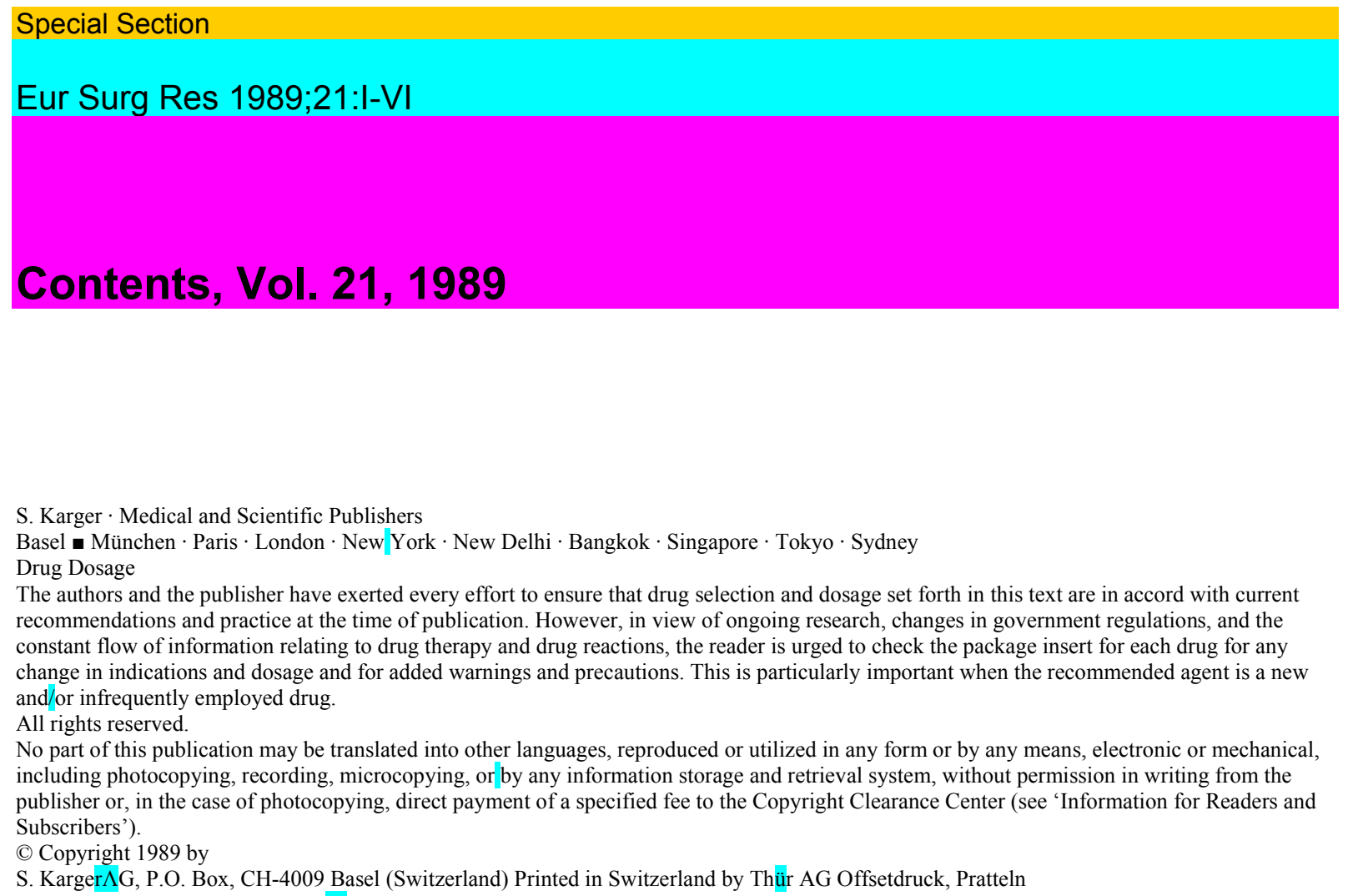

\title{
Contents Vol. 21,1989
}

\section{No. 1 Original Paper}

Peritoneal Lavage Efficiently Eliminates Protease-Alpha-2-Macroglobulin Complexes and

Components of the Contact System from the Peritoneal Cavity in Patients with Severe

Acute Pancreatitis

Aasen, A.O.; Ruud, T.E.; Roeise, O.; Bouma, B.N.; Stadaas, J.0

Inhibition of Proteinases with Recombinant Eglin C during Experimental Escherichia coli

Septicemia in the Pig

Siebeck, M.; Hoffmann, H.; Jochum, M.; Fritz, H 11

Improved Survival with Splenic Autotransplantation and Fibronectin Therapy following

Endotoxin Administration in Rats

Calise, F.; Capron-Laudereau, M.; Gugenheim, J.; Pin, M.-L.; Gigou, M.; Cuomo, O.;

Reynes, M.; Bismuth, $\mathrm{H} \quad 18$

Magnetic Resonance Imaging in Detecting Acute Oedematous and Haemorrhagic Pancreatitis: An Experimental Study in Pigs Puolakkainen, P.; Kivisaari, L.; Sipponen, J.; Standertskjòld-Nordenstam, C.-G.;

Nuutinen, P.; Schöder, T 25

Studies on the Dose Dependence of Endotoxin-Induced in vitro Activation of the Complement System

Roeise, O.; Garred, P.; Mollnes, T.E.; Aasen, A.0 34

Acute Ischemic Liver Failure in the Rat: A Reproducible Model Not Requiring Portal

Decompression

Asakawa, H.; Jeppsson, B.; Mack, P.; Hultberg, B.; Hägerstrand, I.; Bengmark, S. . 42 Effects of

Hyperthermochemoradiotherapy on KSE-1 Cells, a Newly Established Human

Squamous Cell Line Derived from Esophageal Carcinoma

Matsuoka, H.; Sugimachi, K.; Mori, M.; Kuwano, H.; Ohno, S.; Nakano, S 49

Autogenous Skin and Fascia Grafts as Topical Hemostatic Agents in Splenic Injuries

Eitan, A.; Munichor, M.; Barzilai, A 60

\section{No. 2 Original Paper}

Long-Term Survival of Kidney Allografts in Dogs after Withdrawal of Immunosuppression

with Ciclosporin and Azathioprine

Davies, ff. S.H.; St. John Collier, D.; Thiru, S.; Decurtins, M.; Calne, R.Y

65

Restoration of ATP Contents in the Transplanted Liver Closely Relates to Graft Viability 
in Dogs

Higashi, H.; Takenaka, K.; Fukuzawa, K.; Yoshida, Y.; Sugimachi, K 76

IV Contents

Thioacetamide- and Carbon Tetrachloride-Induced Liver Cirrhosis

Dashti, H.; Jeppsson, B.; Hägerstrand, I.; Hultberg, B.; Srinivas, U.; Abdulla, M.; Beng-

mark, S 83

New Intraoperative Biliary Manometric Technique Using a Balloon Catheter - Selective

Evaluation of Papillary Function

Kubota, K.; Itoh, T.; Shibayama, K.; Kosuge, T.; Nomura, Y.; Idezuki, Y

Effects of Partial Deprivation of Portal Blood on Arterial Blood Ketone Body Ratio in

Rabbits

Yamamoto, S.; Nitta, N.; Kamiyama, Y.; Yamaoka, Y.; Ozawa, K 98

Primate Cardiac Allo- and Xenotransplantation: Modulation of the Immune Response with

Photochemotherapy

Pepino, P.; Berger, C.L.; Fuzesi, L.; Panza, A.; Pierson, R.N.; Gutierrez, C; Marboe,

C.C.; Smith, C.R.; Reemtsma, K.; Rose, E.A 105

Blood Mononuclear Cell Production of IL-1 and IL-2 following Moderate Surgical

Trauma

Grzelak, I.; Olszewski, W.L.; Rowinski, W 114

Coronary Artery Plaque Rapidly Induced by Local Electromagnetic Stimulation in the

Baboon

Breuer, H.; Fincham, J.; Hinrichsen, P.; Uys, C.J.; Weich, H.; Reichart, B

\section{No. 3-4 Original Paper}

Disturbances of Reticulo-Endothelial Function following Experimental Liver Transplanta tion

Lahnborg, G.; Bracher, M.; Hickman, R.; Terblanche, J 129

Orthotopic Partial Liver Transplantation in Dogs Can Be Performed without Cold Per-fusion of the Donor Liver. Evaluation of Its Feasibility in Terms of Energy Metabolism

Tokunaga, Y.; Zaima, M.; Tanaka, K.; Maki, A.; Katayama, T.; Sakai, Y.; Egawa, H.;

Kiuchi, T.; Yamamoto, Y.; Ueda, J.; Lin, H.; Kitakado, Y.; Nitta, N.; Kamiyama, Y.;

Yamaoka, Y.; Ozawa, K 137

Changes in Serum Bile Acid Composition in Relation to Histological Findings after Liver Transplantation in Piglets

Okanoue, T.; Kimoto, M.; Maki, A.; Usui, Y.; Nishimura, N.; Kobayashi, N.; Kami

yama, Y.; Ozawa, K 145

Use of Verapamil with Conventional Immunosuppression after Porcine Renal Transplan

tation

Kahn, D.; Hickman, R.; Dreyer, C; Temple Camp, C

156

Pancreaticoduodenal Graft in the Rat: An Original Microsurgical Technique

Benetti, L.; Bassi, C; Zamboni, G.; Radin, S.; Falconi, M.; Girelli, R.; Elio, A.; Briani,

G.F.; Cavallini, G.; Pederzoli, P 162

Pressure-Volume Curve of the Remaining Lung after Lung Resection

Hatakeyama, S.; Harada, K; Saoyama, N.; Monden, Y 168

Morphological and Hemodynamic Changes of the Lung after Injection of 5\% Ethanolamine

Oleate into Dogs

Iso, Y.; Kitano, S.; Iwanaga, T.; Hashizume, M.; Sugimachi, K

1,2-Dimethylhydrazine-Induced Carcinogenesis Influenced by Different Colonic Anasto

moses in Rats

Rokitansky, A.; Trubel, W.; Buxbaum, P.; Moeschl, P 184

Contents V

Famotidine Does Not Inhibit Liver Regeneration

Kanashima, R.; Kobayashi, M 190

Effect of Preoperative 4'-Epidoxorubicin (Epi-Adriamycin) Treatment on the Regeneration and Function of the Liver in Partially Hepatectomized Rats

Hall, K.S.; Lien, B.; Paulsen, J.E.; Clausen, O.P.F.; Bergan, A.; Rugstad, H.E 196

Analysis of Hemodynamics and Blood Gas in Relation to Blood Ketone Body Ratio in

Partially Hepatectomized Patients

Nakatani, T.; Shimahara, Y.; Mori, K.; Kobayashi, N.; Yamaoka, Y.; Kobayashi, K.;

Ozawa, K205

Effect of PGI2 and Thromboxane Antagonist on Liver Ischemic Injury

Besse, T.; Gustin, T.; Claeys, N.; Schroeyers, P.; Lambotte, L

Revised Model for the Study of Colonic Anastomotic Healing in Protein Malnourished

Rats 
Hypoxia Enhances the Lethality of Mitomycin $\mathrm{C}$ and Carboquone against Human Malignant Tumor Cells in vitro

Kusumoto, T.; Maehara, Y.; Sakaguchi, Y.; Saku, M.; Sugimachi, K 224

Announcements 232

No. 5 Obituary

Walter Brendel

Original Paper

Immunological Treatment with Low Dosage Ciclosporin in Rat Liver Allotransplanta-

tion

Okamura, R.; Tanaka, K; Asonuma, K; Uemoto, S.; Katayama, T.; Tanaka, M.;

Utsunomiya, H.; Ozawa, K; Hoshida, T.; Inui, K; Hori, R 235

Effect of Hyperthermia on Isolated Perfused Rat Liver

Zavagno, G.; Vespa, D.; Moschin, N.; Belluco, C; Cecchetto, A.; Bertocco, E.; Raimondo,

A.; Lise, $M \quad 243$

Extent of Hepatectomy in the Rat. Evaluation of Basal Conditions and Effect of Therapy

Emond, J.; Capron-Laudereau, M.; Meriggi, F.; Bernuau, J.; Reynes, M.; Houssin, D. 251 Interleukin-2 and Alpha Interferon

Therapy of Advanced Pulmonary Metastases

Kim, B.; Warnaka, P.; Imbembo, A 260

Preventing Recurrent Postoperative Adhesions: An Experimental Study in Rats

Verreet, P.R.; Fakir, C; Ohmann, C; Röhrer, H.D 267

Comparison of Cardiopulmonary Variables with Intermittent Positive Pressure Ventilation

and High-Frequency Jet Ventilation during Abdominal Aortic Operations

Tabatabai, M.; Javadi, P.P 274

Carbon Tetrachloride-Induced Experimental Cirrhosis in the Rat: A Reappraisal of the

Model

Ariosto, F.; Riggio, O.; Cantafora, A.; Colucci, S.; Gaudio, E.; Mechelli, C; Merli, M.;

Seri, S.; Capocaccia, L 280

Inhibition of Thrombin on Subendothelium. Studies on Rabbit Aorta, ex vivo

Nydahl, S.; Frebelius, S.; Swedenborg, J 287

Announcement 296

VI Contents

\section{No. 6 Original Paper}

Oxygen Free Radical-Induced Histamine Release during Intestinal Ischemia and Reperfusion

Boros, M.; Kaszaki, J.; Nagy, S 297

Piroxicam Affects Collagen Changes around Experimental Intestinal Anastomoses

Mastboom, W.J.B.; Hendriks, T.; Elteren, P. van; Boer, H.H.M. de 305

Multifocal Gastric Cancer in Patients Younger than 50 Years of Age

Furukawa, H.; Iwanaga, T.; Imaoka, S.; Hiratsuka, M.; Fukuda, I.; Kabuto, T.; Ishi-

kawa, O.; Sasaki, Y313

Model of Pulmonary Extravasation as an Effect of Neutropenia in Endotoxic Shock in

Guinea Pigs

Mårtensson, L.; Davidsson, B.; Hultkvist, U

Hemodynamic Effects of Mexiletine and Disopyramide after Cardioplegic Arrest

Moritz, A.; Eckersberger, F.; Losert, U.; Probst, P.; Schreiner, W.; Wolner, E 327

Serial Mixed Lymphocyte Culture Responses in Pigs after Liver or Kidney Auto- or Allotransplantation

Bracher, M.; Hickman, R.; Terblanche, J

Rib Fracture Healing after Osteosynthesis with Wire Mesh Titanium and Screws:

A Histological Study in Sheep

Klein, C.P.A.T.; Lubbe, H.B.M. van der; Gahr, R.H 347

Author Index $\quad 355$

Subject Index $\quad 357$

Suppl. 1 Long Acting Cephalosporins in Surgery

World Congress of the International College of Surgeons Milan, July 3-9, 1988 Guest Editor: K. Hell, Basel

Suppl. 2 European Society for Surgical Research

24th Congress, Brussels 1989

Abstracts

Editors: B. de Hemptinne, Brussels; S. Karran, Southampton; L. Lambotte, Brussels 